\title{
Pendampingan Keluarga untuk Mengatasi Perceraian pada Masa Pandemi Covid-19 di Talu-Pasaman Barat
}

\author{
Mirajun Nasihin \\ Pengadilan Agama Talu, Indonesia \\ mirajunnashin@gmail.com
}

2021 by the authors. Submitted for possible open access publication under the terms and conditions of the Creative Commons Attribution-ShareAlike 4.0 International License-(CC-BY-SA) (https://creativecommons.org/licenses/by-sa/4.0/)

DOI : http://dx.doi.org/10.30983/dedikasia.vlil.4974

\begin{tabular}{ll}
\hline ARTICLE INFO \\
\hline Submit $\quad: 03$ Februari 2021 \\
Revised $\quad: 17$ Arpil 2021 \\
Accepted $\quad: 30$ Juni 2021
\end{tabular}

\section{Keywords:}

Covid-19, Perceraian, Keluarga

International License-(CC-BY-SA)

\section{ABSTRACT}

Penyebaran Covid-19 yang begitu hebat hingga beberapa negara, termasuk Indonesia, telah menyatakan masalah global saat ini. Dampak dari pandemi ini dapat mempengaruhi banyak sektor kehidupan seperti kesehatan, ekonomi, politik dan pendidikan karena penyebaran Covid19 yang begitu cepat, dan pemerintah harus mengeluarkan keputusan untuk mengurangi lonjakan kematian akibat virus tersebut. Di sisi lain, kebijakan ini juga berdampak pada sektor lain, mempengaruhi keutuhan keluarga dan apa yang terjadi di Kabupaten Pasaman Barat pada masa pandemi ini, yang dapat meningkatkan angka perceraian. Untuk menyoroti dampak negatif Covid-19 terhadap tingginya angka perceraian di Pasaman Barat, penulis melakukan pendampingan bagi keluarga yang diambamh perceraian berdasarkan data perceraian yang terdaftar di Pengadilan Agama Talu pada Pengadilan Agama di Pasaman Barat dalam menanggulangi angka perceraian masa pandemi. Dengan demikian, pendampingan dan penyuluhan bagi keluarga diambang perceraian dapat menurunkan tingkat gugatan perceraian selama masa pandemi Covid-19.

This is an open access article under the CC-BY-SA license

\section{Introduction}

Dari sudut pandang aturan hidup, tidak ada keraguan bahwa Islam adalah agama dengan aturan kompleks, yang mengatur tidak hanya Ubudiah tetapi juga etika, budaya, masyarakat dan juga mengatur hubungan antara individu dengan individu, dari hal-hal kecil seperti kehidupan hingga hal-hal besar seperti pernikahan. Pernikahan adalah hal penting yang secara khusus diatur dalam Islam. Karena pernikahan bukan hanya soal Sunnah Nabi, tetapi juga sarana pemenuhan kebutuhan biologis, saling menyayangi, memperhatikan dan memperdulikan antar pasangan dalam ikatan pernikahan.

Sudarsono (1991: 2) mendefinisikan pernikahan sebagai aqad antara laki-laki dan perempuan yang bersifat luhur dan suci untuk menghalalkan hubungan seksual dengan tujuan membentuk keluarga ideal sebagaimana diidam-idamkan masyarakat yang diwujudkan dengan terpenuhinya kasih sayang, kebaikan dan saling menyantuni. Untuk mewujudkan tujuan pernikahan, diperlukan suami dan istri untuk menjalankan hak dan kewajiban masing-masing. Menurut Undang-Undang Nomor 1 Undang-Undang Perkawinan Tahun 1974 Pasal 33, disebutkan bahwa suami dan istri 
berkewajiban untuk saling mengasihi, menghormati, setia, dan memberikan pertolongan lahir dan batin. Darmavati (Wawasan Islam, 11, 2017: 64) menjelaskan bahwa suami istri memiliki kualitas dalam hal kedudukan dalam kehidupan rumah tangga dan masyarakat serta juga mempunyai kesamaan dalam berhadapan di depan hukum.

Dalam pernikahan tidak selalu berada dalam kondisi ideal, karena akan selalu ada halangan dan rintangan dalam kehidupan pernikahan. Pernikahan ideal yang tidak selalu berjalan sesuai rencana, terkadang ada batu-batu kecil yang menghalangi rumah, dan ada juga rintangan seperti batu besar yang menjadi malapetaka bagi pernikahan. Beberapa pernikahan berada dalam keadaan darurat dan tidak dapat diselamatkan, perceraian adalah pintu terakhir yang membuka pintu menuju pernikahan yang indah. Secara sederhana, perceraian dapat diartikan sebagai pemutusan hubungan atau perkawinan karena alasan yang disahkan oleh hakim berdasarkan persyaratan salah satu pihak selain yang diatur dalam Pasal 19 (Simanjuntak: 2007). Sesuai dengan Keputusan Pemerintah Nomor 9 Tahun 1975 juga ditetapkan sebab-sebab sebagai berikut:

1. Salah satu pihak berbuat zina atau menjadi pemabuk, pemadat dan lain sebagainya yang sukar disembuhkan;

2. Salah satu pihak meninggalkan pihak lain selama 2 (dua) tahun berturut-turut tanpa izin pihak lain dan tanpa alasan yang sah atau karena hal lain diluar kemampuannya;

3. Salah satu pihak mendapat hukuman penjara 5 (lima) tahun atau hukuman yang lebih berat setelah perkawinan berlangsung;

4. Salah satu pihak melakukan kekejaman atau penganiayaan yang membahayakan pihak lain;

5. Salah satu pihak mendapat cacat badan atau penyakit dengan akibat tidak dapat menjalankan kewajibannya sebagai suami/istri;

6. Antara suami dan isteri terus menerus terjadi perselisihan dan pertengkaran serta tidak ada harapan akan hidup rukun lagi dalam rumah tangga.

Keenam alasan dan merupakan alasan yang sering disebutkan atau dikemukakan dalam putusan hakim pengadilan agama karena banyak sekali penyebab perselisihan dan pertengkaran antara suami istri, seperti masalah ekonomi dan perselingkuhan. Sikap buruk dari satu pasangan dan yang lain.

Menurut Pengadilan Agama, jumlah perceraian meningkat tajam setiap tahun, meningkat 10\% dari 436.957 pada tahun 2016 menjadi 472.780 pada tahun 2017. Bahkan, pada 2018, angka perceraian di Indonesia kembali naik menjadi 588.266. Angka ini bahkan lebih menarik dari sudut pandang orang yang mengajukan gugatan cerai. Hal ini dikarenakan perceraian yang sebenarnya terjadi di Indonesia lebih banyak dikenal dengan gugatan atau gugatan oleh istri. Sampai dengan angka perceraian tahun 2017, jumlah perceraian yang diajukan oleh istri adalah 276.700 , dan situasi ini terus meningkat seiring dengan meningkatnya jumlah perceraian di Indonesia, hingga jumlah kasus perceraian pada tahun 2019 mencapai 355.800, bahkan jika diambil persentase terjadinya 
perceraian oleh suami dan istri, maka dapat disimpulkan dengan porsi 30:70 persen, dengan dominasi cerai gugat oleh istri atas cerai talak oleh suami (Manna, et al., Al-Azhar, 6, 2021:12).

Situasi di atas sebenarnya semakin memburuk sejak pandemi Covid-19, terlihat dari data perceraian yang dirilis Mahkamah Agung selama pandemi Covid-19. Menurut data ini, ada 20.000 pendaftaran antara April dan Mei 2020, dan bulan berikutnya tepatnya melonjak menjadi 57.000 pada Juni dan Juli, meningkat lebih dari 100.000 pada bulan sebelumnya. Dampak pandemi Covid-19 terhadap keutuhan rumah tangga dan meningkatnya angka perceraian tidak bisa diremehkan, menurut studi tahun 2020 oleh Badan Kependudukan dan Keluarga Berencana Nasional (BKKBN) dan IPB. Semakin parah (Wijayanti, Ilm. Ki \& Sons, 14, 2021: 14), kondisi tersebut menyebabkan banyak keluarga tidak dapat memenuhi kebutuhan keluarganya, seringkali terlibat dalam perselisihan dan pertengkaran keluarga. Hilangnya pendapatan dan alasan lain yang menunjukkan serangkaian konsekuensi dari pandemi Covid-19.

Peningkatan angka perceraian juga terjadi di Pengadilan Agama Talu di Kabupaten Pasaman Barat yang merupakan salah satu dari tiga tingkat perceraian tertinggi di Sumatera Barat. Berdasarkan Sistem Informasi Penelusuran Perkara (SIPP), jumlah perceraian yang didaftarkan ke Pengadilan Agama Talu pada 2019 meningkat dari 554 kasus menjadi 558 kasus pada 2020. Kasus meningkat dari tahun sebelumnya. Namun jumlah perceraian Januari-Juli 2021 sebanyak 413, dan berdasarkan data tersebut dapat disimpulkan bahwa jumlah perceraian Januari-Juli 2020 meningkat signifikan dibandingkan bulan yang sama tahun sebelumnya (2020). Hanya ada 320 perceraian. Dengan demikian, peningkatan dari Januari hingga Juli 2021 adalah 93 kasus.

Dapat disimpulkan bahwa peningkatan angka perceraian yang dijelaskan di atas tidak terlepas dari dampak pandemi Covid-19 yang dimulai pada akhir tahun 2019 dan meningkat pesat hanya di Indonesia sejak Maret 2020. Ini berbasis data. Di Indonesia yang masuk dalam World Health Organization (WHO) untuk Covid-19, dua kasus dilaporkan pertama kali sejak 2 Maret 2020 (Susilo et al., Indonesia Journal of Internal Medicine, 2, 2020: 46). Seringkali, pandemi menciptakan perselisihan internal dan meningkatkan jumlah perceraian. Khususnya karena pandemi berlangsung lama dan berdampak pada sektor kehidupan yang paling penting, seperti ekonomi, pendidikan dan lain-lain, menurut data perceraian, data terakhir yang diterima dari Pengadilan Agama Talu, penulis menemukan ada perbedaan antara wabah pandemi dengan tingginya angka perceraian di Kabupaten Pasaman Barat,.

\section{Methods}

Metode pelaksanaan pengabdian kepada masyarakat ini dilaksanakan dengan metode penyuluhan dan pendampingan dengan dua pendekatan yaitu pendekatan kelompok dan pendekatan individu. Pendekatan kelompok yakni pertama, dengan mendatangi keluarga yang diambang perceraian berdasarkan data dari Pengadilan Agama Talu untuk memberikan penyuluhan secara 
langsung kepada keluarga-keluarga yang diambang perceraian. Kedua, pendekatan individual dilakukan dalam kegiatan pendampingan dengan membimbing dan memberikan penyadaran bagi individu-individu akan dampak buruk perceraian bagi anak agar mereka dapat memperbaiki diri masing-masing dan mengurungkan untuk melakukan perceraian.

Adapun langkah-langkah kegiatan yang dilakukan dalam mencapai tujuan ini adalah seperti berikut ini.

1. Ceramah tentang hakikat perkawinan dalam komitmen membangun kehidupan bersama.

2. Ceramah tentang penyadaran bahwa perkawinan merupakan proses menyatukan karakter yang berbeda.

3. Sosialisasi indikator keluarga bahagia.

4. Proses pendampingan membangun keluarga sakinah.

\section{Results}

Kegiatan Pengabdian ini dilakukan dengan pengabdian masyarakat berbasis riset. Pengabdian berbasis riset dapat dimaknai sebagai kegiatan pengabdian masyarakat yang terlebih dahulu dilakukan riset dan kemudian dilakukan penyuluhan dan pendampingan. Hasil kegiatan pengabdian kepada masyarakat berbasis riset yang dilaksanakan di Talu Kabupaten Pasaman Barat dapat terungkap beberapa masalah yang menjadi penyebab Perceraian dapat terjadi karena beberapa alasan yang dibenarkan oleh undang-undang, seperti perzinahan dan perselisihan yang sedang berlangsung antara para pihak, yang secara jelas diatur dalam Pasal 9, Pasal 19 Ordonansi 1975. Tentang Penerapan Undang-undang Nomor 1 Tahun 1974 tentang Perkawinan dalam kaitannya dengan Pasal 116 Kitab Undang-undang Hukum Islam. Kekhawatiran ini muncul dari pasal 19(6) atau pasal $116 \mathrm{f}$ dari undang-undang tersebut di atas, yaitu, perselisihan dan perselisihan yang sedang berlangsung, yang oleh beberapa pengacara yang berpraktik dapat disebut artikel "tempat sampah". Dalam menggunakan pasal ini perceraian seperti perpisahan selama satu bulan tidak dapat dielakkan, pihak yang berpandangan wajar, dan pihak yang lain mengatakan hal itu merupakan hal yang mendesak karena adanya perselisihan rumah tangga. Cukup fakta dan argumen, kedua belah pihak pasti akan bercerai. Sebelum membahas keterkaitan antara wabah Pasaman Barat dan tingginya angka perceraian, penulis membahas subjek penelitian, data, klasifikasi perceraian membumi dari Januari 2021 hingga Juli 2021 yang terdaftar di Pengadilan Agama Talu, sebagai berikut : 
Tabel.l Klasifikasi Percerain di Pengadilan Agama Talu

\begin{tabular}{lll}
\hline & \multicolumn{1}{c}{ Alasan Perceraian } & Jumlah \\
\hline No & Ekonomi & 62 \\
\hline & & \\
\hline 2 & Meninggalkan salah satu pihak & 31 \\
\hline 3 & Kekerasan dalam rumah tangga & 14 \\
\hline 4 & Dihukum penjara & 2 \\
\hline 5 & $\begin{array}{l}\text { Perselisihan dan Pertengkaran } \\
\text { Terus Menerus }\end{array}$ & \\
\hline & \multicolumn{2}{c}{ Total } \\
\hline
\end{tabular}

Berdasarkan tabel di atas, terlihat bahwa alasan perceraian yang terjadi di kawasan Talu Pasaman Barat sejak Januari hingga Juli 2021 cukup beragam. Hal ini didasarkan pada gejala umum yang terjadi ketika masyarakat mulai merasakan dampak dari pandemi COVID-19 yang terjadi dalam kurun waktu satu tahun, dan tentunya dampak tersebut juga memiliki sebuah dampak interaksi di rumah tangga. Dari tabel diatas terlihat jelas bahwa faktor ekonomi merupakan salah satu penyebab terjadinya perceraian. Adapun kegitan penyuluhan dan pendampingan yang dilakukan sebagai berikut:

\section{Penyuluhan bagi keluarga bermasalah yang di sebabkan Oleh Faktor Ekonomi}

Penyuluhan bagi keluarga yang diambang perceraian yang disebabkan oleh factor ekonomi menjadi prioritas utama, karena masalah ekonomi dalam pengabdian berbasis riset atau menempatkan factor pertama pemicu perceraian adalah masalah ekonomi. Penyuluhan bagi keluarga diambang perceraian ini dilakukan sebagai antisipasi terjadinya perceraian, sehingga dengan kegiatan penyuluhan ini diharapkan, angka perceraian dapat ditekan dan bagi pasangan yang diambang perceraian dapat dapat untuk menangguhkannya dan kembali memperbaiki dan membangun keluarga yang bahagia. Afandi (Al Ahwal, 7, 2014:192195) menerangkan dalam tulisannya bahwa ada kaitan erat antara kondisi ekonomi seseorang dengan ketenangan hidup dalam rumah, sehingga semakin baik kondisi ekonomi suatu rumah tangga maka semakin tenang juga kehidupannya dalam penjelasan lain yaitu semakin terpenuhinya kebutuhan primer dan sekunder suatu rumah tangga maka konflik yang disebabkan permasalahan ekonomi dapat dihindari. 
Pembagian peran di masyarakat tentang kewajiban suami sebagai pencari nafkah untuk kebutuhan ekonomi keluarga yang juga diakomodir oleh undang- undang, menjadi stereotype keluarga ideal yang tertanam di tengah masyarakat indonesia, sehingga jika suami tidak bisa memenuhi kebutuhan rumah tangganya maka akan rentan timbul tuntutan tertentu dari pihak istri dan tidak jarang memicu konflik. Pihak istri sebagai penggugat yang menggugat suaminya dengan alasan sang suami tidak dapat memenuhi kebutuhan ekonomi rumah tangganya dan di klaim sebagai suami yang tidak bertanggung jawab, ketidakbertanggungjawaban suami ini bisa disebabkan beberapa hal, seperti suami malas bekerja, pelit, dan lain lain, sementara dalam perkara cerai talak terkadang suami juga menggugat istrinya karena istri tersebut dianggap tidak mensyukuri apa yang diberikan suami, padahal suami sudah merasa memberikan semua penghasilannya kepada istri" Permasalahan di atas juga dapat ditemukan dalam beberapa posita gugatan perceraian di Pengadilan Agama Talu, seperti perkara nomor 187/Pdt.G/2021/PA TALU yang menerangkan dalil gaugatan sebagaimana berikut: "Tergugat (suami) kurang dapat memberikan nafkah secara layak kepada Penggugat padahal Tergugat bekerja yang penghasilannya hanya untuk dirinya sendiri tanpa memperhatikan Penggugat dan kehidupan rumah tangga bersama dan Tergugat kadang kadang hanya dapat memberikan penghasilan setiap bulannya sebesar Rp500.000,00 (lima ratus ribu rupiah) sehingga tidak dapat memenuhi kebutuhan rumah tangga bersama karena bagi Penggugat minimal kebutuhan setiap bulannya sebesar Rp2.000.000,00 (dua juta rupiah);untuk memenuhinya Penggugat terpaksa bekerja sendiri”

Penyuluhan dan pendampingan bagi keluarga yang konflik dengan alasan ekonomi yang menyebabkan perceraian sebenarnya merupakan permasalahan klasik yang terjadi dan meningkat setiap tahunnya, Lestari (2012:14) menerangkan bahwa persoalan ekonomi terkadang menjadi pemicu terjadinya perceraian karena kebahagiaan sebuah rumah tangga sangat dipengaruhi oleh aspek finansial. Permasalahan ekonomi sebagai penyebab perceraian semakin meningkat pada masa pandemi, hal ini dapat disimpulkan secara sederhana dari tingginya angka perceraian yang terjadi khususnya di Pasaman Barat, pengaruh pandemi Covid-19 terhadap kondisi ekonomi masyarakat memang tidak bisa dipungkiri, pengaruh ini juga dapat dilihat dari data Badan Pusat Statistik (2020) yang menerangkan bahwa pertumbuhan ekonomi Indonesia pada kuartal II (Q2) tahun 2020 mengalami kontraksi sebesar 5,32 persen setiap tahunnya. dan pertumbuhan antar triwulan ekonomi Indonesia triwulan II-2020 - 4,19\%. Angka tersebut lebih buruk dibandingkan triwulan I 2020 (2,97\%) dan triwulan II 2019 (5,05\%).

Pandemi COVID-19 secara tidak langsung telah menciptakan siklus perceraian karena banyak orang kehilangan pekerjaan selama pandemi dan banyak suami yang kehilangan mata pencaharian dan tidak dapat memenuhi kebutuhan hidup rumah tangga. melakukan. Karena telah berdampak buruk pada perekonomian, dan situasi ekonomi keluarga yang memburuk telah menciptakan konflik dan beberapa tidak berakhir dengan perceraian. Peningkatan tajam angka 
perceraian karena faktor ekonomi ini juga dapat ditegaskan dari hasil perbandingan angka perceraian menurut faktor ekonomi selama masa pandemi. Ada 29 perceraian ekonomi dari 352 perceraian pada 2019, tepat sebelum merebaknya pandemi di Indonesia, dan 31 perceraian ekonomi pada awal pandemi pada 2020. Maka penyuluhan dan pendampingan bagi keluarga yang diambang perceraian menjadi suatu yang sangat penting dilakukan pada masa pandemic.

\section{Penyuluhan bagi yang Meninggalkan Salah Satu Pihak}

Penyuluhan dan pendampingan bagi keluarga yang diambang perceraian yang disebabkan oleh salah satu pihak meninggalkan pasanagannya. Sekaitan dengan hal di atas, Hukum Islam dan Hukum Perkawinan juga menjelaskan alasan perceraian. Dengan kata lain, satu pihak meninggalkan pihak lain selama dua tahun berturut-turut tanpa alasan dan izin yang dapat dipertanggungjawabkan. Atau karena alasan lain di luar kemampuannya, dengan sukarela, tetapi berdasarkan alasan-alasan keadaan tersebut dan yang terjadi di wilayah Pasaman Barat. Sebelum melaksanakan kegiatan penyuluhan dan pendampinagn ini juga dilakukan riset awal dengan fakta yang ditemukan dalam beberapa gugatan dalam gugatan yang didaftarkan di nomor Pengadilan Agama Talu. Kasus perceraian sering terjadi karena satu pihak meninggalkan yang lain, meskipun suami lebih sering meninggalkan istri. apakah itu dilakukan karena alasan seperti konflik di masa lalu, atau dilakukan tanpa sebab dalam arti menghilang secara tiba-tiba atau pembangkangan"

Menurut penulis, Pernikahan bukanlah alasan utama perceraian. Ini adalah refleksi atau refleksi atas masalah pernikahan masa lalu. Itu karena tidak mungkin bagi pasangan yang berjanji untuk saling mengikat cinta. Pernikahan di mana salah satu dari keduanya pergi tanpa alasan untuk bertindak. Jika kita melihat tahun sebelumnya dalam hal syarat-syarat keluarnya salah satu pihak sebagai faktor perceraian, beberapa perbandingan berikut ini dapat dipahami mengenai kasus perceraian yang terjadi dari tahun 2019 sampai 2021:

Tabel 2. Perbandingan percerain pada tahun 2019-2021

\begin{tabular}{|c|c|c|c|}
\hline \multicolumn{3}{|r|}{ T Jumlah Kasus } & \multirow[t]{2}{*}{ Periode } \\
\hline No & Tahun & & \\
\hline & 2019 & 21 & Januari-Juli \\
\hline & 2020 & 29 & Januari-Juli \\
\hline & 2021 & 31 & Januari-Juli \\
\hline
\end{tabular}

Pada tabel di atas, tidak ditemukan peningkatan yang signifikan pada periode pra-pandemi, dari awal wabah, atau selama periode puncak pandemi 2021. Kasus di mana satu pihak meninggalkan 
yang lain sebenarnya tidak sama dengan kasus pertengkaran dan pertengkaran yang terus-menerus, tetapi jika Anda melihat lebih dalam ke fase mempertimbangkan kasus ini, Anda akan melihat bahwa masalah utamanya ada di sana. Apa yang menyebabkan konflik batin adalah hancurnya salah satu pihak. Di sisi lain, konflik ini sangat beragam. Misalnya, seorang istri selalu menuntut lebih dari sekadar kemampuan suaminya untuk menyediakan makanan, campur tangan salah satu anggota keluarga atau bahkan lebih. Di mana kepribadian buruk satu pihak memutuskan untuk pergi tanpa tekanan.

\section{Penyuluhan bagi Pelaku dan Korban Kekerasan Dalam Rumah Tangga}

Penyuluhan dan Pendampingan bagi keluarga keluarga diambang perceraian. Untuk mengendalikan kekerasan pada rumah tangga, pemerintah Indonesia membuat aturan khusus dalam Undang-Undang No. 23 Tahun 2004 Tentang Penghapusan Kekerasan Dalam Rumah Tangga. Dalam pasal 5 sampai 9 pada undang-undang tersebut disebutkan bahwa bentuk kekerasan dalam rumah tangga, diantaranya sebagai berikut

1. Kekerasan Fisik

2. Kekerasan Psikis

3. Kekerasan Seksual

4. Penelantaraan Rumah Tangga

Kekerasan fisik merupakan perbuatan yang menyebabkan rasa sakit, jatuh sakit atau luka berat. Kekerasan psikis merupakan perbuatan yang menyebabkan ketakutan, hilangnya rasa percaya diri, hilangnya kemampuan buat bertindak, rasa nir berdaya, atau penderitaan psikis berat dalam seseorang. Kekerasan seksual yg dimaksud pada undang-undang tadi bisa dibagi sebagai 2 bentuk, yaitu;

1. Pemaksaan interaksi seksual yg dilakukan terhadap orang yg menetap pada lingkup tempat tinggal tangga tadi;

2. Pemaksaan interaksi seksual terhadap keliru seseorang pada lingkup tempat tinggal tangganya menggunakan orang lain buat tujuan komersial \&/atau tujuan eksklusif.

Dalam hal penelantaran tempat tinggal tangga, undang-undang tidak mengungkapkan definisinya secara spesifik, tetapi memberi keterangan bahwa setiap orang dilarang menelantarkan orang pada lingkup rumah tangga, padahal menurut hukum yang berlaku baginya atau karena persetujuan atau perjanjian ia wajib memberikan kehidupan, perawatan, atau pemeliharaan kepada orang tersebut. Beberapa perkara perceraian yg terdaftar pada Pengadilan Agama Talu terjadi lantaran perlakuan jelek keliru satu pihak baik suami atau istri, tetapi yg seringkali sekali ditemui merupakan pihak suami menjadi pelaku ad interim pihak istri menjadi korban. Perlakuan jelek tadi sanggup misalnya memukul, menendang, membanting atau bahkan memakai senjata tajam dan pernah beberapa kali ditemukan seorang istri yg tiba ke Pengadilan Agama Talu pada syarat memar masih pada perawatan dokter" Kekerasan rumah tangga seperti ini sangat penting untuk dilakukan 
pengabdian bagi pelaku dan korban kekerasan dalam rumah tangga. Kegiatan pengabdian masyarakat berbasis riset ini dipandang dapat untuk mengurangi dan mengantisipasi perceraian.

Mengutip pendapat Kramarae \& Treichler, Radithya, dkk (Jurnal Kolaborasi Resolusi Konflik, 2, 2020:114) mengungkapkan bahwa kebanyakan korban kekerasan pada rumah tangga merupakan wanita, begitu pula di Indonesia, lantaran budaya patriarki yg mengakar pada negara kita sebagai akibatnya acapkali membuahkan wanita menjadi korban pada kekerasan domestik. Kekerasan dalam rumah tangga sering kali terjadi karena konflik internal yang bisa dipicu oleh berbagai hal. Kekerasan dalam rumah tangga juga merupakan fakta sosial yang bersifat universal tanpa memandang budaya, agama, suju bangsa dan umur pelaku atau korban, bahkan persoalan ini dapat terjadi dalam keluarga sederhana, miskin, kaya, terdidik dan terkenal. Kekerasan ini dapat terjadi kepada siapa saja yang menjadi anggota keluarga seperti suami, istri atau bahkan anak, permasalahan ini juga dapat menggoyahkan sendi-sendi kehidupan rumah tangga sehingga mampu membuat rumah tangga bercerai berai dan berujung pada perceraian (Manan, Legislasi Indonesia, 5, 2008:11).

Pada masa pandemi, kekerasan dalam rumah tangga mempunyai potensi semakin meningkat hal ini karena ada beberapa hal yang bisa membuat masyarakat mengalami depresi, stres, cemas atau gangguan mental lainnya, hal tersebut bisa berupa adanya program dirumah saja yang mengisolasi masyarakat tidak kemana-mana, John Gottman (dalam Gottman \& Declaire, 1998) menyatakan bahwa terjadinya KDRT bisa disebabkan oleh Characterological dan Situational, artinya disebabkan oleh karakter pelaku yang memang memiliki sifat dasar tempramental atau disebabkan kondisikondisi tertentu lain yang mempengaruhi. Kehilangan pekerjaan, terisolasi di rumah, kurangnya penghasilan atau beberapa hal lain yang menjadi dampak nyata dari pandemi ini dapat menjadi penyebab utama yang memicu terjadinya KDRT. Dan kondisi ini yang membuat suami maupun istri sebagai korban KDRT tadi tidak tahan dan merasa harus menyelamatkan dirinya dengan perpisahan dan perceraian. Penyuluhan dan pendampingan bagi pelaku dan korban kekerasan rumah tangga ini sebagai bentuk dari perhatian dan kepedulian bagi keluarga yang bermasalah dan diambang perceraian yang disebabkan oleh kekerasan dalam rumah tangga.

\section{Penyuluhan Bagi yang Dihukum Penjara}

Salah satu pengabdian masyarakat berbasis riset dilakukan bagi yang dihukum penjara dengan alasan yang diperbolehkan secara hukum untuk perceraian adalah salah satu pihak dihukum lima tahun penjara atau lebih setelah menikah. Masalah perceraian salah satu pihak yang dipenjara juga muncul di Kabupaten Pasaman Barat, yang membuktikan bahwa ada dua kasus perceraian karena alasan ini dari Januari hingga Juli 2021.

Penyuluhan dan Pendampingan kasus ini sangat penting dilakukan mengingat awalnya rumah tangga pelapor dan tergugat rukun, tetapi pada tanggal 20 Mei 2015, terdakwa melakukan persekongkolan jahat untuk mengenai penjualan barang terlarang, dan ditangkap pada tanggal 20 
Mei 2015 dengan melakukan perbuatan yang melanggar hukum. Kasus kedua awalnya rumah tangga pengadu dan tergugat telah hidup rukun dan harmonis sejak menikah, dan hidup dalam keluarga yang harmonis, namun mulai tanggal 3 April 2017, rumah tangga pengadu dan tergugat mulai kurang berkembang. Terdakwa divonis penjara seumur hidup lima tahun enam bulan atau lebih. Dua perceraian yang disebutkan di atas didasarkan pada hukuman penjara yang dieksekusi sebelum pandemi 2021, tetapi mengingat situasi pandemi saat ini, kemungkinan melakukan kejahatan jauh lebih tinggi. Seperti yang diketahui bersama, pandemi covid-19 tidak hanya berdampak pada sektor kesehatan, tetapi juga sektor sosial dan ekonomi lokal, akibatnya banyak perusahaan yang merasakan ketidakstabilan dan krisis di lingkungan ekonomi menerapkan PHK besar-besaran karena untuk efisiensi.

Penyuluhan dan pendampingan bagi istri yang suaminya dipenjara sangat rentan untuk mengajukan cerai ke Pengadilan Agama. Pendampingan ini sangat penting dilakukan mengingat dampak pandemi terhadap bisnis kreatif seperti pengusaha dan pedagang yang harus menyelamatkan usahanya selama pandemi. Kondisi ini membuat orang tidak dapat memenuhi kebutuhan sehari-hari, dan banyak orang memilih untuk melakukan hal-hal yang dilarang, seperti pencurian, perampokan, perjudian, perdagangan narkoba, atau hal lain yang terancam hukuman yang lebih berat. Ini sesuai dengan teori kriminologi klasik. Penyebab aktivitas kriminal yang lebih tinggi adalah ekonomi. Anwar ('Adalah, 4, 2020: 105) menjelaskan bahwa dewasa ini masyarakat perlu mewaspadai tingginya angka kriminalitas yang terjadi bukan hanya karena masyarakat khawatir dengan masalah Covid-19, tetapi juga karena banyak masyarakat yang menderita masalah ekonomi. dan beberapa melakukannya. . Mereka buta dan dibenarkan dengan cara apapun, bahkan cara kriminal.

Covid-19 sebenarnya telah menyebabkan kepanikan masyarakat karena jumlah kejahatan jalanan seperti perampokan meningkat sejak kemunculan Covid-19 di Indonesia, karena dampaknya sangat luas dan memanifestasikan dirinya di semua bidang seperti kesehatan, politik, pendidikan dan bidang sosial. Perampokan dan pembongkaran minimarket, Minggu. Selama periode ke-18, 3.244 insiden keamanan dilaporkan selama pandemi, dengan peningkatan 299 pada minggu ke-19 menjadi 3.473. https://www.merdeka.com/events/polri (disebut sebagai pelanggaran keamanan selama penyebaran pendemi covidl9.html), l Juli 2021 Akses Jika Anda terlibat dalam kegiatan kriminal seperti perjudian dan narkoba, Anda dapat menghilangkan stres dan memperbaiki situasi ekonomi. Melarikan diri dianggap sebagai cara tercepat untuk memperbaiki. Salah satu penyebab perceraian saat kasus kriminal meningkat selama pandemi adalah para pihak berada di penjara. Maka penyuluhan dan pendampingan bagi yang rentan untuk mengajukan gugatan cerai bagi suami yang sedang dipenjara sangat penting untuk dilakukan. 
5. Penyuluhan Bagi keluarga yang Rentan Perceraian disebabkan oleh Perselisihan Dan Pertengkaran

Perceraian dengan alasan perselisihan dan pertengkaran terus menerus merupakan alasan perceraian yang tertinggi di Pengadilan, ini tidak hanya terjadi di Pengadilan Agama Talu, namun terjadi hampir di seluruh Pengadilan Agama yang ada di Indonesia, hal ini karena kompleksitas permasalahan yang terjadi dalam suatu rumah tangga, mulai dari hal kecil hingga hal besar atau bahkan hal yang oleh sebagian orang dianggap kecil namun oleh para pihak dianggap besar. Perselisihan dan pertengkaran terus menerus juga merupakan pasal yang dapat mengakomodir permasalahan rumah tangga yang tidak dapat diakomodir dengan pasal pasal lain, misal salah satu alasan perceraian yaitu meninggalkan salah satu pihak, dalam faktanya ada keluarga yang masih tinggal dalam satu rumah namun sering sekali terjadi pertengkaran hebat diantara keduanya, disinilah peranan urgen dari alasan perselisihan dan pertengkaran terus menerus untuk membela kepentingan pihak yang ingin mengajukan perceraian". Maka penyuluhan dan pendampingan yang dilakukan bagi keluarga yang rentan perceraian yang disebabkan oleh perselisihan dan penting dilakukan untuk menanggulangi dan mengantisipasi terjadinya kasus perceraian yang disebabkan oleh perselisihan dan pertengkaran. Beberapa kasus yang terjadi, mengenai perceraian yang diseabkan perselisihan dan pertengkaran umumnya disebabkan oleh termohon lebih mementingkan diri sendiri daripada kepentingan pemohon, seperti dalam menyediakan makan untuk pemohon atau mencuci pakaian pemohon sehingga tak jarang pemohon sendiri yang melakukannya walaupun sebenarnya hal tersebut adalah tanggung jawab termohon selaku istri dalam rumah tangga, termohon kurang menghargai pemohon sebagai seorang suami yang sah, yakni termohon terlalu berani dan seringkali membantah perkataan pemohon dalam rangka membina rumah tangga yang baik, termohon tidak mau diajak tinggal dan pindah ke rumah sendiri tanpa alasan yang jelas sedangkan termohon tidak betah tinggal di rumah kediaman bersama di rumah orang tua pemohon dengan alasan karena pemohon berprinsip ingin mencoba hidup mandiri akan tetapi termohon tidak mau. Kasus-kasus di atas menjadi contoh pemicu terjadinya gugatan dalam perceraian. Untuk itu, pengabdian masyarakat berbasis riset yang dilakukan sebagai antisipasi terjadinya perceraian yang disebabkan oleh perselisihan dan petengkaran.

Beberapa alasan di atas merupakan sebagian dari banyaknya alasan perceraian yang disebabkan perselisihan dan pertengkaran terus menerus di Pengadilan Agama talu, alasan ini merupakan alasan terbanyak yang mendasari terjadinya perceraian, sebagaimana dalam tabel tentang alasan perceraian sebelumnya, di Pengadilan Agama Talu yang mewilayahi kabupaten Pasaman Barat dalam kurun waktu Januari hingga Juli 2021 terjadi perceraian dengan alasan tersebut sebanyak 304 kasus yang berarti 73,6\% dari perceraian yang terjadi di Pengadilan Agama Talu dalam kurun waktu tersebut disebabkan alasan perselisihan dan pertengkaran terus menerus.

Suhendi dan Wahyu (2001) menjelaskan bahwa ketidakmampuan pasangan menghadapi perbedaan keluarga merupakan penyebab utama perselisihan dan konflik keluarga, dan jika 
perselisihan ini berlanjut, kehidupan pernikahan yang kokoh akan berlanjut di masa depan. di ambang kehancuran. Selain itu penyebab perselisihan dan pertengkaran antara suami istri terkadang juga dipengaruhi oleh orang ketiga. Perselingkuhan akan senantiasa memberikan dampak buruk pada kehidupan rumah tangga dan menurut Surya (2009), perselingkuhan biasanya terjadi pada keluarga yang kurang memiliki kualitas keagamaan, egois, buruknya komunikasi dan kurang menyesuaikan diri

Menurut sebagian ulama, alasan perceraian yang disebutkan dalam Pasal 19 f Keputusan Pemerintah Nomor 9 Tahun 1975 di pengadilan agama, yaitu adanya perselisihan dan pertengkaran yang terus-menerus, tidak selalu disebut shikaku (Manan, 2005: 387). Rekonsiliasi visual dalam Inkuisisi dicapai dengan cara khusus, dengan keluarga sebagai hakim antara pihak yang bersengketa dan selalu diperhitungkan dalam kasus perceraian akibat perselisihan dan perselisihan.

Geogde menjelaskan bahwa teori fungsi struktural memandang masyarakat sebagai bagian yang saling berhubungan dalam keadaan keseimbangan, dan oleh karena itu, dengan pemahaman ini, setiap struktur sosial akan dipengaruhi oleh sistem sosial yang terjadi di sekitarnya. Berdasarkan teori tersebut, dapat dijadikan sebagai alat untuk menganalisis peningkatan angka perceraian selama masa pandemi (Tristanto, Sosio Informa, 6, 2020: 298). Perubahan tertentu dalam unsur keluarga akan menciptakan ketidakseimbangan dalam rumah tangga, yang akan menimbulkan konflik internal dan pada akhirnya berdampak negatif yang lebih besar lagi bagi keluarga jika tidak ditangani dengan baik.

Faktor yang meningkat signifikan sebagai penyebab perceraian di masa pandemi adalah faktor ekonomi, yang terkait dengan dampak pandemi terhadap penurunan ekonomi yang tajam (Hitubun, Psikologi Pendidikan dan Konseling, 2, 2020: 146); Fakta tersebut adalah sebagai berikut. Sebuah studi yang didukung oleh Fauzia dkk (Hukum Islam, 4, 202: 181) menemukan bahwa tingkat perceraian meningkat sebesar 5\% selama pandemi Indonesia. Pendampingan dan penyuluhan bagi keluarga yang rentan perceraian yang disebabkan oleh perselisihan dan pertengkaran dalam upaya menanggulangi peningkatan angka perceraian juga terjadi di Pengadilan Agama Talu yang berada di Kabupaten Pasaman Barat.

\section{Discussion}

\section{Pendampingan dan Penyuluhan Untuk Antisipasi perceraian di masa pandemi}

Penyuluhan dan pendampingan yang dilakukan bagi keluarga-keluarga yang rentan perceraian khususnya pada masa pandemi Covid-19, pandemi secara tidak langsung berubah menjadi hantu yang menakutkan di dalam rumah. Ini berarti bahwa kedua pasangan telah menyerah pada masalah mereka dan merasa tidak memiliki harapan untuk hidup dengan ikatan keluarga. Persyaratan terakhir ini dapat ditarik dari fenomena umum di masyarakat yang membuat perceraian menjadi hal yang memalukan bagi keluarga untuk dihindari. 
Terdapat beberapa undang-undang dan peraturan tentang perceraian (misalnya Pasal 31) yang tampaknya mempersulit perceraian. Mediasi pengadilan yang secara khusus mengatur penyelesaian sengketa, serta Pasal 115 Hukum Islam, yang mengatur bahwa perceraian dapat dikabulkan setelah pengadilan berusaha mendamaikan kedua belah pihak. Kasus mediasi, termasuk kasus perceraian. Karena begitu banyak aturan ketat tentang perceraian, kita dapat berasumsi dan menduga bahwa undang-undang dan peraturan juga secara eksplisit melarang perceraian dan harus dihindari dalam kehidupan keluarga.

Dari penjelasan hubungan pandemi dengan meningkatnya angka perceraian di atas, terlihat bahwa faktor utama penyebab perceraian di masa pandemi Covid-19 adalah situasi ekonomi keluarga. Ia menjadi salah satu sektor yang terdampak di masa pandemi ini. Ketika sebuah keluarga memiliki masalah keuangan, seringkali menyertai masalah lain, seperti kesulitan menghidupi keluarga selama masa-masa sulit, kekerasan dalam rumah tangga karena frustasi atas beban keuangan keluarga, dan paling sering perselisihan rumah tangga. Seperti sisik kecil yang memecahkan rumah. Rumah atau skala besar menempatkan salah satu pihak dalam bahaya. Oleh karena itu, tidak berlebihan jika dikatakan bahwa biang keladi utama yang mengganggu keharmonisan keluarga dan menimbulkan masalah yang berujung pada perceraian adalah ekonomi.

Bahwa ekonomi keluarga menjadi masalah utama bagi rumah tangga di masa pandemi, perlu dilakukan langkah-langkah untuk mengantisipasi masalah ini dengan menanamkan kembali pemahaman kepada pasangan tentang fungsi keluarga yang dapat dipahami sebagai salah satu fungsi keluarga Keluarga adalah fungsi ekonomi. Menurut Badan Koordinasi dan Keluarga Berencana Nasional (BKKBN), keluarga memiliki delapan fungsi utama yaitu: fungsi religi, fungsi sosial budaya, fungsi kasih sayang, fungsi pelindung, fungsi reproduksi, fungsi sosialisasi dan pendidikan, fungsi ekonomi, dan fungsi lingkungan.

Memang, selama pandemi, peningkatan fungsi ekonomi keluarga mungkin berasal dari dalam keluarga inti atau keluarga besar. Misalnya, untuk keluarga inti, hal ini dimungkinkan selama pandemi, mengelola perencanaan keuangan (setoran dan penarikan), saling mendukung dalam kegiatan yang dapat mengurangi kebutuhan yang tidak perlu, fokus pada kebutuhan dasar dan meningkatkan kondisi ekonomi, atau untuk keluarga besar dimungkinkan. . Misalnya saling tolong menolong, antar anggota keluarga, saling membantu meringankan beban keluarga yang lain, saling meminjamkan uang atau barang-barang yang diperlukan untuk kehidupan keluarga, dan hal-hal lain yang dapat menunjang kehidupan keluarga. Diharapkan dengan peningkatan fungsi ekonomi keluarga ini, konflik dalam keluarga yang dapat berujung pada perceraian dapat dikurangi.

Penyuluhan dan pendampingan bagi keluarga yang bermasalah dan rentan perceraian baik yang disebabkan oleh factor ekonomi, meninggalkan salah satu pihak, korban kekerasan rumah tangga, suami yang sedang menjalani hukuman penjara serta masalah perselisihan dan pertengkaran yang menjadi pemicu perceraian dipandang salah satu cara efektif dalam mengurangi angka perceraian dalam perkawinan. 


\section{Conclusion}

Dampak dari pandemi Covid-19 yang sangat separatisme di berbagai bidang seperti pendidikan, ekonomi, kesehatan politik dan lainnya menimbulkan permasalahan tersendiri, termasuk keluarga. Peningkatan 5\% angka perceraian di Indonesia selama masa pandemi menjadi bukti bahwa pandemi Covid-19 telah memberikan dampak nyata terhadap keutuhan keluarga, baik secara langsung maupun tidak langsung. Kekhawatiran kesehatan selama pandemi memaksa pemerintah untuk mengambil beberapa langkah untuk mencegah penyebaran Covid-19, seperti social distancing, karantina, penyiaran layanan masyarakat, dan kebijakan PPKM.

Sementara itu, kebijakan tersebut telah memberikan dampak yang signifikan bagi masyarakat, seperti kehilangan pekerjaan, pendapatan menurun, stres dan efek negatif lainnya. Dampak dari beberapa kebijakan ini berdampak besar pada integritas seluruh rumah. Perceraian karena berbagai alasan, termasuk keadaan ekonomi, unilateralisme, kekerasan dalam rumah tangga, pemenjaraan, dan perkelahian terus menerus. Dengan banyaknya perceraian yang terjadi di masa pandemi ini, pasangan suami istri di rumah perlu memahami kembali fungsi keluarga, terutama ekonomi, dengan memperbaiki keuangan rumah tangga dan menjadi unit yang saling mendukung antar keluarga. Akibatnya, tingkat perceraian diperkirakan akan melonjak selama periode Covid-19. Penyuluhan dan pendampingan bagi keluarga yang rentan perceraian sebagai dampak ekonomi sebagai salah satu bentuk kepedulian dan pengabdian kepada masyarakat untuk mengantisipasi terjadinya perceraian khususnya lonjakan perceraian pada masa pandemi.

\section{Bibliography}

Aris, T. (2021). Perceraian Di Masa Pandemi Covid-19 Dalam Perspektif Ilmu Sosial. Jurnal Sosio Informa .

Darmawati, H. (2017). Percerain Dalam Perspektif Sosiologi. Jurnal Wawasan Keislaman .

Fauziah, A. F. (2020). Analisis Maraknya Perceraian Pada Masa Pandemi Covid-19. Jurnal Islamic Law .

Gottman, J. \&. (1998). Raising An Emotionally Intelligent Child The Heart of Parenting. New York: Simon\&Schuster Paperback.

Hanoatubun, S. (2020). Dampak Covid-19 Terhadap Perekonomian Indonesia (Universitas Kristen Satya Wacana). Jurnal Education, Psychology, and Counseling .

Lestari, S. (2012). Psikologi Keluarga. Jakarta: Kencana Prenada Media Grup.

Manna.S.N \& Oktaviani, M. (2021). Cerai Gugat: Telaah Penyebab Perceraian Pada Keluarga Di Indonesia. Jurnal AL-Azhar .

Mardeka. (01 Juli 2021). Polri Sebut Gangguan Keamanan Selama Masa Pandemi Covid-19 Meningkat.

Moch, A. (2014). Hukum Perceraian di Indonesia: Studi Komparatif antara Fikih Konvensional, UU Kontemporer di Indoesia Dan Negar-negara Muslim Perspektif HAM Dan CEDAW. Jurnal AlAhwal Hukum Keluarga Islam .

Mohamad, A. (2020). Asimilasi dan Peningkatan Kriminalitas Di Tengah Pembatasan Sosial Berskala 
Besar Pandemi Corona. Jurnal ‘Adalah .

Radhitya.V.t, N. I. (2020). Dampak Pandemi Covid-19 Terhadap Kekerasan Dalam Rumah Tangga. Jurnal Kolaborasi Resolusi Konflik .

Simanjuntak. (2007). Pokok-Pokok Hukum Perdata Indonesia. Jakarta: Pustaka Djamban.

Sudarsono. (1991). Hukum Perkewaninan National. Jakarta: Renika Cipta.

Suhendi \& Wahyu, R. (2001). Pengantar Sosiologi Keluarga. Bandung: Pustaka Setia.

Surya, M. (2009). Bina Keluarga. Bandung: Graha Ilmu.

Susilo Adityo, d. (2020). Coronavirus Disease 2019: Tinjauan Literatur Terkini. Jurnal Penyakit Dalam Keluarga .

Urip, W. T. (2014). Analisis Faktor Penyebab Percerain Pada Masa Pandemi Covid-19 Di Kabupaten Banyumas. Jurnal Ilm.Kel\& Kons . 